\title{
PENGARUH KOMPENSASI DAN GAYA KEPEMIMPINAN TRANSFORMASIONAL TERHADAP MOTIVASI KERJA KARYAWAN CV.HEARTWARMER ACCSSESORIES \& GIFTS
}

\author{
Herina D.N Riwu Mone ${ }^{1}$, Rusmin Nuryadin ${ }^{2}$ \\ 1,2 Universitas Sangga Buana YPKPafiliasi penulis pertama \\ ${ }^{1}$ korespondensi : deamone08@gmail.com
}

\begin{abstract}
The development of commerce or business has increased remarkably, such as the accessories business which is experiencing significant growth. In this globalization era, many business people take advantage of this opportunity, for instance, CV. Heartwarmer Accessories \& Gifts, To deal with such a competition, business people have to work hard in improving the product quality and service efficiency of the company supported by competent human resources. The research was done due to the large number of employees who often experience work stress and the company's lack of understanding of the employees' needs in terms of work motivation. This research was conducted at CV. Heartwarmer Accessories \& Gifts. The purpose of this study is to determine the effects of compensation and transformational leadership style on employee work motivation, both partially and simultaneously. The method of the research is a descriptive verification method with a quantitative approach. This research used 91 respondents as research samples using multiple linear regression analysis. The results of the descriptive research show that low work motivation is influenced by compensation that does not comply with government regulations and the improper implementation of transformational leadership styles to the employees. In addition, the results of the verification research show that compensation and transformational leadership styles significantly influence work motivation, both partially and simultaneously.
\end{abstract}

Keyword : Compensation, Transformational Leadership style, Work Motivation

\begin{abstract}
ABSTRAK
Perkembangan usaha atau bisnis sangat meningkat salah satunya adalah bisnis aksesoris yang sedang mengalami pertumbuhan cukup signifikan. Pada era globalisasi ini pasti banyak pelaku bisnis yang memanfaatkan peluang ini, seperti CV.Heartwarmer Accssesories \& Gifts. untuk menghadapi persaingan, pelaku bisnis ini harus bekerja keras dalam meningkatkan kualitas produk dan efisiensi pelayanan perusahaan yang didukung oleh sumber daya manusia yang kompeten. Penelitian ini dilatar belakangi dengan banyaknya karyawan yang seringkali mengalami stress kerja dan tidak pahamnya perusahaan akan kebutuhan karyawan dalam meningkatkan motivasi kerja karyawan. Penelitian ini dilakukan di CV.Heartwarmer Accssesories \& Gifts, Tujuan penelitian ini yaitu untuk mengetahui pengaruh Kompensasi Dan Gaya Kepemimpinan Transformasional Terhadap Motivasi Kerja Karyawan baik secara parsial maupun secara simultan. Penelitian ini menggunakan 91 responden sebagai sampel penelitian dengan menggunakan analisis regresi linier berganda. Hasil penelitian menunjukan bahwa secara deskriptif motivasi kerja yang rendah yang dipengaruhi oleh kompensasi yang tidak sesuai dengan peraturan pemerintah dan gaya kepemimpinan transformasional yang tidak diterapkan dengan tepat kepada karyawan. Adapun secara verifikatif menunjukan bahwa kompensasi dan gaya kepemimpinan transformasional berpengaruh secara signifikan terhadap motivasi kerja baik secara parsial maupun simultan.
\end{abstract}

Kata kunci : kompensasi, gaya kepemimpinan transformasional, motivasi kerja

\section{PENDAHULUAN}

Sumber daya manusia merupakan salah satu faktor penting dalam suatu kegiatan organisasi atau dalam sebuah perusahaan. Perusahaan tanpa karyawan yang kompeten, maka perusahaan itu tidak akan mampu bertahan.
Tercapainya tujuan perusahaan tidak hanya bergantung pada kualitas barang atau jasa yang dimiliki perusahaan saja tetapi justru bergantung pada sumber daya manusia yang melaksanakan pekerjaan pada perusahaan tersebut. Selain karyawan yang kompeten, 
perusahaan juga membutuhkan karyawan yang memiliki motivasi kerja yang tinggi dalam melaksanakan tangung jawabnya, karena semakin tinggi motivasi kerja karyawan, maka semakin mudah bagi perusahaan untuk mencapai tujuan perusahaan. permasalahan yang dihadapi oleh CV.Heartwarmer Accssesories \& Gifts merupakan masalah pengolahan sumber daya manusia yang terfokus pada motivasi kerja karyawan, "Motivasi kerja merupakan hasil dari kumpulan kekuatan secara internal dan eksternal yang mendorong pekerja memilih jalan bertindak yang sesuai dan menggunakan perilaku tertentu' [1]. oleh karena itu motivasi kerja sangat penting perannya dalam meningkatkan efisiensi kerja karyawan, dan untuk mempengaruhi karyawan dibutuhkan kompensasi, "Kompensasi merupakan semua pendapatan yang berbetuk uang, barang langsung atau tidak langsung yang diterima oleh karyawan sebagai imbalan atas jasa yang diberikan kepada perusahaan atau instalasi'” [2] dan pemberian kompensasi yang sesuai dengan beban kerja karyawan dapat mempengaruhi motivasi kerja karyawan sehingga timbul suatu keyakinan pada karyawan yang apabila bekerja pada perusahaan dapat memenuhi kebutuhan hidup karyawan, selain kompensasi gaya kepemimpinan transformasional juga memiliki peran penting dalam meningkatkan motivasi kerja karyawan, 'Gaya kepemimpinan transformasional merupakan suatu gaya kepemimpinan yang dianggap memiliki pendekatan yang paling aktif dan efektif bagi karyawan, dan secara universal diusahakan di seluruh budaya'[1]. Oleh karena itu gaya kepemimpinan transformasional merupakan pola gaya kepemimpinan yang paling baik untuk diterapkan dalam perusahaan sehingga dapat mempengaruhi motivasi kerja karyawan yang akan berdampak positif pada perusahaan. Kompensasi dan gaya kepemimpinan transformasional merupakan hal yang memiliki peran penting dalam menjaga motivasi kerja karyawan bahkan meningkatkan motivasi kerja karyawan. Karena dengan pemberian kompensasi yang sesuai dan memadai serta gaya kepemimpinan transformasional yang tepat maka akan dapat memotivasi karyawan untuk berusaha bekerja dengan efektif dan efisien sehingga pekerjaannya dapat berhasil dan memberikan hasil yang diharapkan perusahaan.

Berdasarkan permasalahan yang sering dilihat di CV.Heartwarmer Accesories \& Gifts informasi serta pengamatan yang dilakukan menunjukan adanya karyawan yang tidak stabil keadaanya melihat keahlian dari tugas pokok dan tangung jawab setiap bidang memungkinkan adanya beberapa faktor yang mempengaruhi salah satunya adalah motivasi kerja yang menurun yang juga dipengaruhi oleh kompensasi dan gaya kepemimpinan dalam perusahaan yang berdampak pada sulitnya karyawan bekerja secara maksimal dan keadaan yang menekan karyawan dalam bekerja, maka peneliti mengambil judul 'Pengaruh Kompensasi Dan Gaya Kepemimpinan Transformasional Terhadap Motivasi Kerja Karyawan Pada Cv.Heartwarmer Accssesories \& Gifts Area Bandung,' 


\section{TINJAUAN PUSTAKA}

\section{Kompensasi}

Kompensasi memiliki keterkaitan dengan motivasi kerja karyawan, dimana semakin tinggi pemberian kompensasi dapat memicu meningkatnya motivasi kerja karyawan, maka akan semakin meningkatnya kepuasan kerja karyawan. Jika kompensasi dikelola dengan baik maka akan membantu perusahaan untuk mencapai tujuan dalam pemeliharaan dan penjagaan karyawan tetap optimal dalam melaksanakan tangung jawabnya. 'kompensasi adalah semua pendapatan yang berbentuk uang, barang langsung dan tidak langsung yang diterima karyawan sebagai imbalan atas jasa yang diberikan kepada perusahaan atau instalasi' '[2]. Berdasarkan pendapat ahli dapat ditarik kesimpulan bahwa pengertian kompensasi merupakan sebuah imbalan yang diberikan perusahaan kepada karyawan atas hasil kinerjanya, baik dalam bentuk keuangan maupun non keuangan, dengan tujuan agar karyawan menjadi lebih giat dalam melakukan pekerjaanya dan menaikan motivasi kerja karyawan.

\section{Gaya Kepemimpinan Transformasional}

Berhasil atau gagalnya perusahaan dalam mencapai tujuan perusahaan dipengaruhi oleh cara pemimpin dalam memimpin perusahaannya. Sosok pemimpin dalam perusahaan akan menjadi lebih efektif apabila pemimpin mampu untuk mengelola perusahaannya dan mampu mempengaruhi perilaku bawahannya agar mau bekerja sama dalam mencapai tujuan perusahaan.
'Transformasional leadership/ gaya kepemimpinan transformasional adalah perspektif kepemimpinan yang menjelaskan bagaimana pemimpin mengubah tim atau organisasi dengan menciptakan, mengkomunikasikan dan membuat model visi untuk organisasi atau unit kerja dan memberi inspirasi pekerja untuk berusaha mencapai visi tersebut', [1].

Dengan demikian dari pendapat ahli dapat disimpulkan bahwa kepemimpianan berhubungan dengan proses mempengaruhi, dalam hal ini merupakan proses mempengaruhi dengan sengaja dilakukan oleh seseorang terhadap orang lain untuk menyusun aktivitas-aktivitas serta hubungan dalam organisasi yang bertujuan untuk mencapai tujuan organisasi.

\section{Motivasi Kerja}

'motivasi merupakan kegiatan yang mengakibatkan, menyalurkan, dan memelihara perilaku manusia"'[3]. Suatu motivasi cenderung mengurangi kekuatanya apabila tercapainya suatu kepuasan, terhalangnya pencapaian kepuasan, perbedaan kognisi, frustasi atau karena kekuatan motivasinya bertambah. Motivasi berdasarkan hierarki teori kebutuhan manusia "pada diri setiap manusia itu terdiri atas lima (5) kebutuhan yaitu kebutuhan fisik, kebutuhan rasa aman, kebutuhan social, kebutuhan pengakuan dan kebutuhan aktualisasi diri'’[4].

Dari pendapat para ahli diatas dapat menarik kesimpulan bahwa motivasi merupakan dorongan yang timbul dari dalam individu 
maupun dari luar untuk mencapai tujuan atau keinginan dalam dirinya.

\section{Hipotesis}

'Hipotesis penelitian adalah sebagai jawaban sementara terhadap rumusan masalah penelitian, kebenaran dari hipotesis harus dibuktikan melalui data yang dikumpulkan"[5]. Sedangkan secara statistic hipotesis diartikan sebagai pernyataan mengenai keadaan populasi (parameter) yang akan di uji kebenarannya berdasarkan data yang diperoleh dari sampel penelitian. Adapun hipotesis dalam penelitian ini adalah sebagai berikut :

1. kompensasi berpengaruh secara signifikan terhadap motivasi kerja karyawan pada CV.Heartwarmer Accessories \& Gifts.

2. gaya kepemimpinan transformasional berpengaruh secara signifikan terhadap motivasi kerja karyawan CV.Heartwarmer Accessories \&Gifts.

3. kompensasi dan gaya kepemimpinan transformasional berpengaruh secara signifikan terhadap motivasi kerja karyawan pada CV.Heartwarmer

Accessories \& Gifts.

\section{METODE PENELITIAN}

Jenis pendekatan yang digunakan dalam penelitian ini adalah metode penelitian deskriptif dan verifikatif, data penelitian yang diperoleh diolah dan dianalisis secara kuantitatif. Dengan menggunakan metode penelitian akan diketahui hubungan signifikan antara variable yang diteliti sehingga kesimpulan akan memperjelas gambaran mengenai objek yang diteliti. Metode pengambilan sampel menggunakan probability sampling. Variable dalam penelitian ini yaitu variable bebas (X1) kompensasi,(X2) gaya kepemimpinan transformasional dan variable terikat (Y) motivasi kerja.

Sesuai dengan tujuan penelitian danhipotesis dalam penelitian, maka terdapat tiga variable yang akan diteliti, yang terdiri dari dua variable bebas (independent) dan satu variable terikat

(dependent), yaitu: 


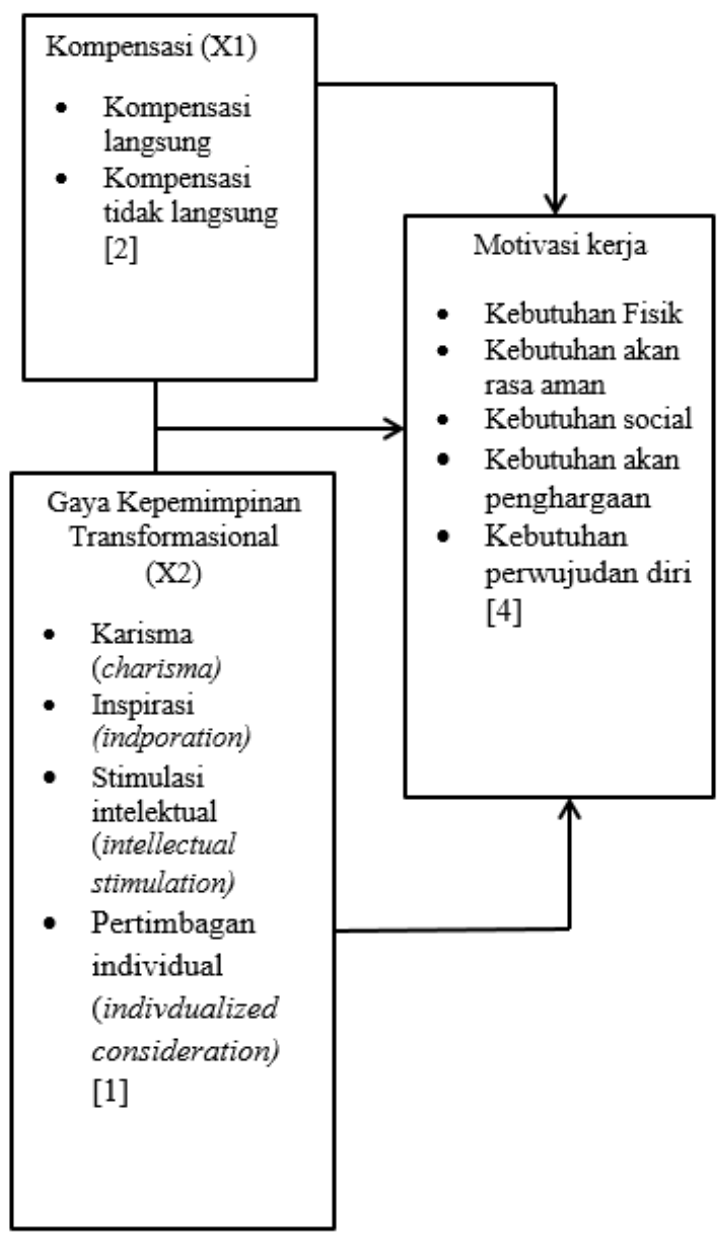

Gambar 1 : Paradigma Penelitian

Analisis Regresi Linier Berganda

Analisis regresi linier berganda merupakan suatu analisis yang memiliki hubungan linier antara satu variable dependent $(\mathrm{Y})$ dan dua atau lebih variable independent (X).Adapun persamaan regresi linier berganda dirumuskan seperti ini :

$Y=\alpha+b_{1} X_{1}+b_{2} X_{2}+\epsilon$

Keterangan :

Y : Variabel dependen (motivasi kerja)

$\alpha \quad$ : konstanta

b : koefisien regresi

$\mathrm{X}_{1} \quad$ : variable independen 1 (kompensasi)

$\mathrm{X}_{2}$ : variable independen 2 (Gaya Kepemimpinan)

$\in \quad$ : Error, variable gabungan

\section{Uji Secara Parsial (uji t)}

Adapun kriteria pengujian untuk memperoleh kesimpulan adalah sebagai berikut :

Penetuan daerah krisis secara parsial adalah sebesar 95\% dengan taraf nyata 5\% $(\alpha=$ 0,05). Tingkat signifikan 0,05 atau $5 \%$

Statistic uji $\mathrm{t}$

Derajat kepercayaan yang digunakan dalam penelitian ini sebesar $\mathrm{df}=\mathrm{dk}=\mathrm{n}-2$.

a. H0 diterima jika : $-\mathrm{t}_{\text {tabel }}<\mathrm{t}_{\text {hitung }}$ atau $\mathrm{t}_{\text {hitung }}$ $<t_{\text {tabel }}$

b. H0 ditolak jika : $t_{\text {hitung }}>t_{\text {tabel }}$ atau $t_{\text {hitung }}<-$ tabel

Apabila H0 diterima, artinya pengaruh variabel independen secara parsial terhadap variabel dependen dianggap tidak signifikan. 
Apabila H0 ditolak, artinya pengaruh variabel independen terhadap variabel dependen dianggap berpengaruh secara signifikan.

Perhitungan $\mathrm{t}$ Hitung

Rumus : $t_{\text {hitung }=\frac{b}{s b}} \cdots$ (...

\section{Uji secara Simultan (uji F)}

Uji $F$ digunakan untuk mengetahui apakah ada pengaruh secara simultan antara variable bebas dan variable terikat. Kriteria pengujia untuk memperoleh kesimpulan sebagai berikut :

Penentuan daerah krisis secara simultan adalah 95\% dengan taraf nyata 5\% $(\alpha=$ $0,05)$. Tingkat signifikansi 0,05 atau 5\%.

Statistic uji F

Derajat kepercayaan yang digunakan dalam penelitian ini sebesar $\mathrm{df}_{1}=\mathrm{k}$ sedangkan $\mathrm{df}_{2}=$ n-k-1.
a. $\mathrm{H} 0$ diterima jika $\mathrm{F}_{\text {hitung }}<\mathrm{F}_{\text {tabel }}$
b. $\mathrm{H} 0$ ditolak jika $\mathrm{F}_{\text {hitung }}>\mathrm{F}_{\text {tabel }}$

Apabila H0 diterima artinya pengaruh variabel independen secara simulatan terhadap variabel dependen dianggap tidak signifikan. Apabila H0 ditolak, artinya pengaruh variabel independen secara simultan terhadap variabel dependen dianggap berpengaruh secara simultan.

\section{Perhitungan $\mathbf{F}$ Hitung}

Rumus : $\mathrm{F}_{\text {hitung }}=\frac{R^{2} / k}{\left(1-R^{2}\right) /(n-k-1)} \ldots$

\section{HASIL PENELITIAN}

\section{Analisis Regresi Linier Berganda}

Analisis regresi linier berganda digunakan untuk mengetahui keadaan variable dependen apabila variable independent yang menjadi faktornya, berikut hasil analisis :

Tabel 1 : Hasil Analisis Regresi Linier Berganda

\begin{tabular}{|c|c|c|c|c|c|c|c|c|}
\hline \multicolumn{9}{|c|}{ coefficients $^{\mathrm{a}}$} \\
\hline \multirow{2}{*}{\multicolumn{2}{|c|}{ Model }} & \multicolumn{2}{|c|}{$\begin{array}{l}\text { Unstandardized } \\
\text { Coefficients }\end{array}$} & \multirow{2}{*}{$\begin{array}{c}\text { Standardized } \\
\text { Coefficients } \\
\text { Beta }\end{array}$} & \multirow{2}{*}{$\mathrm{T}$} & \multirow{2}{*}{ Sig. } & \multicolumn{2}{|c|}{ Collonearity Statistics } \\
\hline & & B & $\begin{array}{l}\text { Std. } \\
\text { Error }\end{array}$ & & & & Tolerance & VIF \\
\hline 1 & (Constant) & 7,890 & 1,936 & & 4,076 & 0,000 & & \\
\hline & Kompensasi X1 & 0,229 & 0,068 & 0,278 & 3,392 & 0,001 & 0,656 & 1,524 \\
\hline & $\begin{array}{l}\text { Gaya kepemimpinan } \\
\text { transformasional X2 }\end{array}$ & 0,366 & 0,051 & 0,578 & 7,165 & 0,000 & 0,656 & 1,524 \\
\hline
\end{tabular}

a. Dependent Variabel : motivasi kerja $\mathrm{Y}$

Sumber : Hasil pengolahan SPSS 23.0

Berdasarkan hasil pada table di atas, diperoleh persamaan regresi sebagai berikut : $Y=7,890+0,229 X_{1}+0,366 X_{2}+\epsilon$ Berdasarkan persamaan yang diperoleh dapat dijelaskan model regresi,sebagai berikut :
1. Nilai konstanta sebesar 7,890 artinya apabila variabel independen kompensasi dan gaya kepemimpinan transformasional bernilai kontan maka motivasi kerja bernilai 7,890 satuan. 
2. Kompensasi memiliki nilai positif sebesar 0,229. Hal ini menujukan bahwa setiap ada peningkatan kompensasi sebesar 1 satuan, maka variabel motivasi kerja akan mengalami peningkatan sebesar 0,229 .

3. Gaya kepemimpinan transformasional memiliki nilai positif sebesar 0,366. Hal ini menunjukan bahwa setiap ada peningkatan gaya kepemimpinan sebesar 1 satuan, maka variable motivasi kerja akan mengalami peninkatan sebesar 0,366 .

\section{Koefisien Detarminasi}

Besarnya presentase variable independent dapat menjelaskan variable dependent dapat diketahui dari besarnya nilai koefisien determinasi yang sudah disesuaikan (adjusted $R$ square).

Tabel 2 : Hasil Koefisien Determinasi

\begin{tabular}{|c|c|c|c|c|c|}
\hline \multicolumn{7}{|c|}{ Model Summary $^{\mathbf{b}}$} \\
\hline Model & R & R Square & $\begin{array}{c}\text { Adjusted R } \\
\text { Square }\end{array}$ & $\begin{array}{c}\text { Std. Error of } \\
\text { the Estinate }\end{array}$ & $\begin{array}{c}\text { Durbin- } \\
\text { Watson }\end{array}$ \\
\hline 1 & $.823^{\mathrm{a}}$ & 0,692 & 0,685 & 2,71539 & 1,643 \\
\hline
\end{tabular}

a. Predictors : (constant), gaya kepemimpinan transformasional, kompensasi

b. Dependent Variabel : Motivasi Kerja

Sumber : Hasil Pengolahan SPSS 23.0

Dari hasil table koefisien determinasi diketahui bahwa $\mathrm{r}^{2}$ sebesar 0,692 atau 69,2 $\%$, yang artinya kompensasi dan gaya kepemimpinan transformasional memiliki pengaruh yang kuat terhadap motivasi kerja karyawan sebesar $69,2 \%$ dan sisanya dipengaruhi oleh faktor lain yang tidak di teliti.

\section{Pengujian Hipotesis}

Uji hipotesis merupakan jawaban sementara terhadap rumusan masalah penelitian. Dibawah ini akan dijelaskan mengenai pengujian hipotesis secara parsial (uji t) dan secara simultan (uji F ), yaitu sebagai berikut:

\section{Pengujian Hipotesis secara Parsial (uji t)}

Uji t dilakukan untuk mengetahui signifikan pengaruh variable bebas secara parsial terhadap variable terikat. Dengan mengunakan tingkat keyakinan $\alpha$ sebesar 5\% dan derajat kebebasannya (n-2). Kemudian dibandingkan antara $t_{\text {hitung }}$ dan $t_{\text {tabel. }}$ Langkahlangkah dalam pengujian hipotesis sebagai berikut :

1. Penetapan penerimaan dan penolakan dugaan atas hipotesis yang diajukan dengan kritesia pengujian sebagai berikut :

a. H0 diterima jika $-\mathrm{t}_{\text {hitung }}<\mathrm{t}_{\text {tabel }}$ atau

$$
\mathrm{t}_{\text {hitung }}<\mathrm{t}_{\text {tabel }}
$$



b. H0 ditolak jika $t_{\text {hitung }}>t_{\text {tabel }}$ atau $t_{\text {hitung }}>-t_{\text {tabel }}$

2. Penetapan hipotesis

$\mathrm{H}_{0}$ : Kompensasi tidak berpengaruh terhadap motivasi kerja karyawan

$\mathrm{H}_{\mathrm{a}}$ : Kompensasi berpengaruh terhadap motivasi kerja karyawan

$\mathrm{H}_{0} \quad$ : Gaya kepemimpinan transformasional tidak berpengaruh terhadap motivasi kerja karyawan

$\mathrm{H}_{\mathrm{a}}$ : Gaya kepemimpinan transformasional berpengaruh terhadap motivasi kerja karyawan
3. Penetapan $t$ table

Dengan mengunkan tingkat signifikan 5\% dan derajat kebebasan (dk) untuk menguji pengaruh $d k=n-2$, maka dapat dilihat nilai $\mathrm{t}$ table untuk menguji dua arah dengan 91 responden adalah 1,98698 .

4. Pengujian

Berikut ini adalah hasil pengujian dari pengolahan data yang talah dilakukan :

Tabel 3 : Hasil Uji t

\begin{tabular}{|c|c|c|c|c|c|c|c|c|}
\hline \multicolumn{9}{|c|}{ coefficients $^{\mathrm{a}}$} \\
\hline \multirow{2}{*}{\multicolumn{2}{|c|}{ Model }} & \multicolumn{2}{|c|}{$\begin{array}{c}\text { Unstandardized } \\
\text { Coefficients }\end{array}$} & \multirow{2}{*}{$\begin{array}{c}\begin{array}{c}\text { Standardized } \\
\text { coefficients }\end{array} \\
\text { Beta }\end{array}$} & \multirow{2}{*}{$\mathrm{t}$} & \multirow{2}{*}{ Sig. } & \multicolumn{2}{|c|}{$\begin{array}{l}\text { Collinearity } \\
\text { Statistics }\end{array}$} \\
\hline & & B & Std. & & & & tolerance & VIF \\
\hline \multirow[t]{3}{*}{1} & (Constant) & 7,890 & 1,936 & & 4,076 & 0,000 & & \\
\hline & Kompensasi & 0,229 & 0,068 & 0,278 & 3,392 & 0,001 & 0,656 & 1,524 \\
\hline & $\begin{array}{l}\text { Gaya Kepemimpinan } \\
\text { Transformasional }\end{array}$ & 0,366 & 0,051 & 0,587 & 7,165 & 0,000 & 0,656 & 1,524 \\
\hline
\end{tabular}

a. Dependent Variabel : Motivasi Kerja

Sumber : Hasil Pengolahan SPSS 23.0

Berdasarkan hasil uji di atas, diketahui hasil pengujian hipotesis diperoleh nilai $\mathrm{t}$ hitung untuk vasibale kompensasi 3,392 dan $t$ tabel 1,98698. Oleh karena hasil pengujian memperoleh nilai $\mathrm{t}_{\text {hitung }}$ lebih besar dari $\mathrm{t}_{\text {tabel }}$ $(3,329>1,98698)$ dengan nilai signifikan lebih kecil dari $0,05(0,001<0,05)$ maka $\mathrm{H}_{0}$ ditolak dan $\mathrm{H}_{\mathrm{a}}$ diterima. Artinya kompensasi berpengaruh signifikan terhadap motivasi kerja.

Berdasarkan hasil uji pada tabel, diketahui hasil pengujian hipotesis diperoleh nilai $\mathrm{t}$ hitung untuk variable gaya kepemimpinan transformasional 7,165 dan $\mathrm{t}$ tabel 1,98698 . Oleh karena itu hasil pengujian memperoleh nilai $\mathrm{t}$ hitung lebih besar dari $\mathrm{t}$ tabel $(7,165$ > 1,98698) dengan nilai signifikan lebih kecil dari $0,05(0,000<0,05)$ maka $\mathrm{H}_{0}$ ditolak dan $\mathrm{H}_{\mathrm{a}}$ terima, artinya gaya kepemimpinan transformasional berpengaruh signifikan terhdap motivasi kerja.

\section{Pengujian Hipotesis Secara Simultan (uji} F)

Uji F dilakukan untuk mengetahui pengaruh variable bebas sacara simultan terhadap variable terikat. Berikut adalah langkahlangkah dalam pengujian hipotesis : 
1. Menentukan penerimaan dan penolakan dugaan hipotesis yang diajukan dengan kriteria pengujian, sebagai berikut :

a. H0 diterima jika $F_{\text {hitung }}<\mathrm{F}_{\text {tabel }}$

b. $\mathrm{H} 0$ ditolak jika $\mathrm{F}_{\text {hitung }}>\mathrm{F}_{\text {tabel }}$

2. Penentuan hipotesis

HO : tidak terdapat pengaruh antara kompensasi dan gaya kepemimpinan transformasional terhadap motivasi kerja.

$\mathrm{H}_{\mathrm{a}}$ : terdapat pengaruh antara kompensasi dan gaya kepemimpinan transformasional terhdapa motivasi kerja.

3. Penentuan F tabel

Dengan menggunakan tingkat signifikan 5\% maka dapat dilihat nilai $\mathrm{F}$ tabel untuk menguji dua arah dengan jumlah responden 91 adalah 3,10 .

4. Pengujian

Berdasarkan langkah diatas berikut adalah hasil dari pengolahan data yang dilakukan :

Tabel 4 : Hasil Uji F

\begin{tabular}{|l|l|c|c|c|c|c|}
\hline \multicolumn{2}{|c|}{ Model } & $\begin{array}{c}\text { Sum of } \\
\text { Squares }\end{array}$ & Df & Mean Square & F & \multirow{2}{*}{ Sig. } \\
\hline \multirow{2}{*}{1} & Regression & 1461,002 & 2 & 730,501 & 99,073 & $.000^{\mathrm{b}}$ \\
\cline { 2 - 7 } & Residual & 648,855 & 88 & 7,373 & & \\
\cline { 2 - 7 } & Total & 2108,856 & 90 & & & \\
\hline
\end{tabular}

a. Dependent Variabel : Motivasi Kerja

b. Predictors : (constant), gaya kepemimpinan transformasional, kompensasi Sumber : Hasil Pengolahan SPSS 23.0

Berdasarkan hasil uji pada tabel di atas, diketahui hasil pengujian hipotesis diperoleh nilai $\mathrm{F}_{\text {hitung }}$ sebesar 99,073 dan $\mathrm{F}_{\text {tabel }}$ sebesar 3,10. Oleh karena itu diperolah nilai $\mathrm{F}$ hitung lebih besar dari $\mathrm{F}_{\text {tabel }}(99,073>3,10)$ dengan nilai signifikanlebih kecil dari $0,05(0,000<$ 0,05) maka $\mathrm{H} 0$ ditolak dan $\mathrm{H}_{\mathrm{a}}$ diterima, artinya kompensasi dan gaya kepemimpinan transformasional secara bersama-sama berpengaruh secara signifikan terhadap motivasi kerja CV.Heartwarmer Accssesories \& Gifts.

\section{Pembahasan}

Berdasarkan penjelasan sebelumnya, berikut ini merupakan pembahasan yang dapat di peroleh dari pengolahan data mengenai pengaruh kompensasi dan gaya kepemimpinan transformasional terhadap motivasi kerja karyawan CV.Heartwarmer Accssesories \& Gifts area Bandung.

\section{Pengaruh Kompensasi terhadap Motivasi}

\section{Kerja}

Kompensasi berpengaruh secaea signifikan terhadap motivasi kerja karyawan. Hal ini ditunjukan pada hasil uji hipotesis pada uju $\mathrm{t}$ yang mana nilai $\mathrm{t}$ hitung lebih besar dari ttabel dengan nilai signifikansi yang lebih kecil dari 0,05 . Oleh karena itu H0 ditolak dan $\mathrm{H}_{\mathrm{a}}$ diterima, dengan demikian hal ini sesuai dengan paradigma penelitian yakni kompensasi merupakan salah satu faktor 
yang mempengaruhi motivasi kerja karyawan.

Hasil dari pengujian ini menunjukan bahwa setiap peningkatan kompensasi maka motivasi kerja karyawan juga akan meningkat. Kompensasi merupakan semua pendapatan yang dapat berupa uang, barang langsung atau tidak langsung yang diterima oleh karyawan sebagai imbalan atas jasa yang diberikan kepada perusahaan (Hasibuan 2017:118). Pemberian kompensasi yang sesuai akan dapat mempengaruhi motivasi kerja karyawan yang dapat dilihat dari peningkatan minat karyawan dalam bekerja dengan lebih baik. Hal ini dapat berpengaruh positif terhadap perusahaan karena dapat mempercepat pencapaian tujuan dari perusahaan.

Hasil penelitian ini sesuai dengan hasil penelitian sebelumnya yang berjudul Pengaruh Kompensasi, Kompetensi, dan Motivasi Terhadap Kinerja Karyawan CV.Xyz. berdasarkan hasil penelitian ini menyatakan bahwa pemberian insentif atau kompensasi berpengaruh positif dan signifikan terhadap motivasi kerja karyawan juga terhadap kinerja karyawan [6]. Penelitian ini menyatakan bahwa motivasi kerja akan tercipta apabila pemberian kompensasi atau insentif kepada karyawan sesuai dengan tangung jawab kerja karyawan yang diberikan kepada karyawan.
Pengaruh Gaya Kepemimpinan Transformasional terhadap Motivasi kerja karyawan

Gaya kepemimpinan transformasional berpengaruh secara signifikan terhadap motivasi kerja karyawan. Hal ini dilihat dari hasil uji hipotesis dimana nilai $t$ hitung lebih besar sari $t$ tabel dengan nilai signifikansi yang lebih kecil dari 0,05. Maka H0 ditolak dan $\mathrm{H}_{\mathrm{a}}$ diterima dengan demikian hasil ini sesuai dengan paradigma penelitian yakni gaya kepemimpinan transformasional merupakan salah satu faktor yang mempengaruhi motivasi kerja karyawan.

Hasil pengujian menunjukan bahwa setiap peningkatan pada gaya kepemimpinan transformasional maka akan ada peningkatan pada motivasi kerja karyawan. Apabila gaya kepemimpinan transformasional diterapkan dengan baik dan benar maka akan berpengaruh positif terhadap motivasi kerja karyawan karena pola kepemimpinan yang insiatif dan membangun sangat berpengaruh terhadap motivasi kerja karyawan yang mana akan memberikan manfaat yang besar terhadap perusahaan dan perusahaan dapat menjaga hubungan yang baik dengan karyawan.

Hal ini sesuai dengan penelitian yang sebelumnya dengan judul Pengaruh Kepemimpinan Transformasioanl Terhadap Motivasi Kerja dan Kinerja Karyawan. Berdasarkan penelitian ini menyatakan bahwa gaya kepemimpinan transformasional secara positif dan signifikan terhadap motivasi kerja karyawan [7]. Penelitian ini menyatakan bahwa gaya kepemimpinan 
transformasional yang semakin kuat pemahaman dan pelaksanaannya maka semakin kuat motivasi kerja karyawan.

\section{Pengaruh Kompensasi dan Gaya}

Kepemimpinan

Transformasional terhadap Motivasi kerja Karyawan

Kompensasi dan gaya kepemimpina transformasional berpengaruh secara signifikan terhdap motivasi kerja karyawan. Hal ini berdasarkan hasil uji hipotesis yang mana nilai f hitung lebih besar dari f tabel, dengan nilai signifikan yang lebih kecil dari pada 0,05. Oleh karena itu $\mathrm{H} 0$ ditolak dan $\mathrm{H}_{\mathrm{a}}$ diterima, dengan demikian hal ini sesuai dengan paragdigma penelitian yang menunjukan bahwa kompensasi dan gaya kepemimpinan transformasional berpengaruh secara bersama-sama terhadap motivasi kerja karyawan.

Kemudian melalui koefisien determinasi diketahui bahwa kompensasi dan gaya kepemimpinan transformasioanal memiliki kontribusi perngaruh terhadap motivasi kerja karyawan sebesar o,692. Artinya motivasi kerja karyawan CV.Heartwarmer Accssesories \& Gifts disebabkan oleh kompensasi dan gaya kepemimpinan transformasional sebesar $69,2 \%$, sedangkan sisanya dipenagruhi oleh faktor lain yang tidak diteliti.

Hal ini sesuai dengan penelitian sebelumnya dengan judul gaya kepemimpinan transformasional dan kompensasi pada kinerja pegawai dengan motivasi berperestasi sebagai variable intervening. Berdasarkan penelitian ini menyatakan adanya pengaruh signifikan antara gaya kepemimpinan transformasional dan kompensasi pada pegawai dengan motivasi berprestasi kerja karyawan [8].

\section{KESIMPULAN}

1. Kompensasi berpengaruh secara signifikan teradap motivasi kerja karyawan CV.Heartwarmer Accssesories \& Gifts. hal ini berdasarkan hasil pengujian hipotesis yang mana nilai $t$ hitung lebih besar dari $\mathrm{t}$ tabel dengan nilai signifikan yang lebih kecil dari pada 0,05 , yang artinya setiap peningkatan kompensasi , maka motivasi kerja juga akan meningkat. Kompensasi memiliki pengaruh yang cukup besar pada motivasi kerja karyawan yang bertujuan untuk dapat mempengaruhi pola kerja karyawan yang berdampak pada tercapainya tujuan perusahaan. Apabila pemberian kompensasi yang kurang sesuai maka akan berpengarugi pada motivasi kerja karyawan karena keryawan merasa bahwa kebutuhannya tidak terpenuhi ketika bekerja pada perusahaan.

2. Gaya kepemimpinan transformasional berpengaruh signifikan terhadap motivasi kerja karyawan CV.Heartwarmer Accssesories \& Gifts. hal ini dapat dilihat pada hasil uji hipotesis yang mana nilai t hitung lebih besar dari pada $t$ tabel dengan nilai signifikan lebih kecil dari 0,05 , yang berarti setiap peningkatan gaya 
kepemimpinan transformasional maka akan meningkatkan motivasi kerja karyawan. Apabila gaya kepemimpinan transformasional diterapkan dengan baik dan benar maka akan mampu mempengaruhi motivasi kerja karyawan karena pola kepemimpinan yang efektif, efisien dan mampu mengkomunikasikan tujuan perusahaan kepada karyawan dengan baik maka akan berpengaruh kepada motivasi kerja karyawan karena karyawan memahami dengan benar tujuan perusahaan.

3. Besar pengaruh kompensasi dan gaya kepemimpinan transformasional melalui koefisien determinasi memiliki kontribusi pengaruh sebesar 69,2\%. Sedangkan sisanya dipengaruhi oleh faktor lain yang tidak diteliti. Hal ini berarti setiap peningkatan kompensasi dan gaya kepemimpinan transformasional secara bersama-sama akan meningkatkan motivasi kerja karyawan. Motivasi kerja ditunjukan dengan perubahan kinerja dan tercapainya tujuan perusahan yang dapat dilakukan oleh karyawan. motivasi kerja sendiri dapat dipengaruhi oleh berbagai faktor tetapi dengan pemberian kompensasi yang sesuai dengan beban kerja dan pola kepemimpinan yang tepat dapat berpengaruh langsung kepada pencapaian tujuan perusahaan.

\section{DAFTAR PUSTAKA}

[1 Wibowo. 'Perilaku Dalam Organisasi'". Edisi Ketiga. Depok : Rajawali Pers, 2017.

[2] Malayu, S.P Hasibuan. 'Manajemen Sumber Daya Manusia”. Jakarta : PT. Bumi Aksara, 2017.

[3] Darodjat, Achmad Tubagus, 'KonsepKonsep Dasar Manajemen Personalia Masa Kini'”. Bandung : Refika Aditama, 2015.

[4] Maslow, Abraham yang dialih bahasakn oleh Achmad Fawaid, "Motivation and Personality (Motivasi dan Kepribadian)', Yogyakarta : Cantrik Pustaka,2017.

[5] Sugiyono.'Metode Penelitian Kuantitatif, Kualitatif, dan R\&D'. Bandung : Penerbit Alfabeta,2018..

[6] Alwi, Muhamad.'Pengaruh Kompensasi, Kompetensi dan Motivasi terhadap Kinerja Karyawan CV.Xyz'. Jurnal Logika, Vol.XIX No.1, 2017. [Online] available: http://jurnal.ugj.ac.id/index.php/logika/a rticle/view/558

[7] Tucuan, Roy Johan Agung ,et al., 'Pengaruh Kepemimpinan Transformasional terhadap Motivai kerja dan Kinerja Karyawan". E- Jurnal Ekonomi dan Bisnis Universitas Udayana 3.9, 2014 : 433-550. ISSN : 2337-3067,2014. [online] avalaible : https://ojs.unud.ac.id/index.php/EEB/arti cle/view/8084

[8] Andiarso, et al.,' 'Gaya Kepemimpinan Transformasional dan Kompensasi pada Kinerja Pegawai dengan Motivasi Berprestasi sebagai Variabel Intervening'. Jurnal PROSIDING SEMINAR NASIONAL \& CALL FOR PAPERS. ISBN : 978-602-14119-2-6, 2017. [online] available : http://feb.untagsmg.ac.id/prosiding/inde x.php/feb/article/view/32 